\title{
El contencioso de interpretación en materia fiscal y administrativa. Un modelo de justicia para México
}

\author{
Marco Aurelio NúÑez Cú́*
}

Sumario. I. Introducción. II. El contencioso de interpretación. 1. Concepto y origen. 2. Naturaleza jurídica y objeto. III. Notas generales del recurso de interpretación en Venezuela. IV. Figuras jurídicas no jurisdiccionales en México similares al contencioso de interpretación en la vía de recurso directo de interpretación. 1 . La consulta ante la Procuraduría de la Defensa del Contribuyente. 2. La consulta ante el Servicio de Administración Tributaria v. Conclusiones y propuesta para la implementación en México del contencioso de interpretación en la vía de recurso directo de interpretación. Referencias.

\section{Resumen}

El autor esboza sus reflexiones acerca de la conveniencia de la implementación en
México del contencioso de interpretación en materia fiscal y administrativa, en la vía de recurso directo de interpretación, haciendo notar las ventajas y beneficios que dicho procedimiento proporcionaría a la justicia administrativa federal mexicana.

\section{Introducción}

"No se colocó la última piedra del
Estado de Derecho hasta que se
implantó la justicia administrativa".

Gustav Radbruch

El artículo 17 de la Constitución Política de los Estados Unidos Mexicanos dispone que toda persona tiene derecho a que se le administre justicia por tribunales que estarán expeditos para impartirla en los plazos y términos que fijen las leyes, emitiendo

\footnotetext{
* Licenciado en Derecho por el ITESO. Maestría en juicio de amparo y maestría en fiscal por la Universidad del Valle de Atemajac, Campus Guadalajara. Doctor en Derecho por el Instituto Internacional del Derecho y del Estado. Profesor del posgrado en Derecho de la Universidad de Guadalajara, de la Universidad Panamericana, Campus Guadalajara y del ITESO. Coordinador de la Comisión de Derecho Fiscal de la Barra Mexicana, Colegio de Abogados, A.C., Capítulo Jalisco. Ha sido Académico Numerario de la Academia Mexicana de Derecho Fiscal, A.C., y es Miembro de Número del Colegio Nacional de Profesores e Investigadores de Derecho Fiscal y Finanzas Públicas, A.C. Profesor ITESO. Guadalajara, Guadalajara, México. Correo-e: marcocue@iteso. mex. Para citar el artículo: Núñez, M. (2016). "El contencioso de interpretación en materia fisal y administrativa. Un modelo de justicia para México". Revista de Derecho Fiscal n. ${ }^{\circ}$, Bogotá: Universidad Externado de Colombia. pp. 9-35. DOI: http://dx.doi.org/10.18601/16926722.n8.02 Agradezco al Dr. Eugenio Herrera Palencia, Juez de la Corte Primera de lo Contencioso-administrativo, Accidental "F", del Tribunal Supremo de Justicia de la República Bolivariana de Venezuela, por la información brindada para la elaboración de este trabajo.
} 
sus resoluciones de manera pronta, completa e imparcial. Su servicio será gratuito, quedando, en consecuencia, prohibidas las costas judiciales (Constitución Política de los Estados Unidos Mexicanos artículo 17); en el ámbito internacional, el derecho fundamental a que alude el citado numeral constitucional se encuentra contenido en los artículos 8 y 25 de la Convención Americana sobre Derechos Humanos -de observancia obligatoria para el Estado Mexicano- previendo el denominado derecho de la tutela judicial efectiva.

Es evidente que hoy en día la justicia administrativa en México, específicamente la que se imparte en el Tribunal Federal de Justicia Fiscal y Administrativa, es lenta $\mathrm{y}$, por consecuencia, ha generado un importante rezago en ese órgano de justicia, especialmente en la tramitación del juicio contencioso-administrativo federal. Tal circunstancia genera un incumplimiento con lo que mandata el artículo 17 constitucional, así como los numerales 8 y 25 de la Convención Americana sobre Derechos Humanos.

El rezago jurisdiccional que afecta al Tribunal Federal de Justicia Fiscal y Administrativa constituye no solo un problema para dicho órgano jurisdiccional, sino también para los derechos fundamentales de los justiciables, en la medida en que el retraso en la atención y resolución de los asuntos vulnera constantemente, en perjuicio de los particulares, los derechos humanos previstos en las referidas normas constitucionales y convencionales, a grado tal que el sentir generalizado de los usuarios de los servicios que presta el Tribunal Federal de Justicia Fiscal y Administrativa, es en el sentido de que dicho órgano de justicia no imparte una verdadera justicia administrativa pronta y expedita.
Para hacer frente al rezago jurisdiccional, en el año 2009, el Ejecutivo Federal, el Tribunal Federal de Justicia Fiscal y Administrativa y los legisladores federales adoptaron medidas para desarrollar e implementar el ambicioso, novedoso y moderno proyecto de justicia fiscal y administrativa denominado "juicio en línea". Aunado a lo anterior y con idéntico fin, se reformó la Ley Federal de Procedimiento Contencioso-Administrativo para crear una nueva modalidad de juicio, el llamado juicio en la vía sumaria, teniendo este como característica principal la simplificación y abreviación de los términos procesales.

A pesar de lo anterior, en el referido órgano de justicia actualmente se sigue observando rezago jurisdiccional, por lo que resulta necesario implementar nuevos mecanismos para hacer frente al mismo y así poder cumplir con el derecho fundamental previsto en el artículo 17 de la Constitución General de la República, así como con el derecho de la tutela judicial efectiva establecido en los artículos 8 y 25 de la Convención Americana sobre Derechos Humanos.

Tradicionalmente, en el sistema contencioso-administrativo francés se distinguen cuatro tipos de contencioso: el de interpretación, el de represión, el de anulación y el de plena jurisdicción. En el caso mexicano, solo se prestó atención a los dos últimos, dejando de lado al denominado contencioso de interpretación. El contencioso de interpretación -también conocido en otras latitudes como recurso contencioso-administrativo de interpretación, recurso de interpretación, o simplemente acción de interpretación-, es aquel que puede promoverse con motivo del surgimiento de una cuestión prejudicial de índole administrativa en una jurisdicción distinta de la contencioso-administrativa 
(prejudicialidad administrativa en un proceso ordinario) (Brewer-Carias \& Pérez Olivares, 1965, pág. 111) o también en forma autónoma, como un recurso directo de interpretación de actos, contratos administrativos y leyes, según sea el caso. El recurso directo de interpretación tiene por objeto solicitar a un juez una declaración sobre la interpretación que debe dársele a un acto, contrato administrativo o a una ley, cuyo sentido y alcance sea oscuro, ambiguo o confuso, a efectos de que determine la correcta interpretación de los mismos.

En la jurisdicción contencioso-administrativa federal mexicana, la única aproximación al contencioso de interpretación la encontramos en la Ley Orgánica del Tribunal Federal de Justicia Fiscal y Administrativa, específicamente en la fracción VII del artículo 14, que dispone:

El Tribunal Federal de Justicia Fiscal y Administrativa conocerá de los juicios que se promuevan contra las resoluciones definitivas, actos administrativos y procedimientos que se indican a continuación: VII. Las que se dicten en materia administrativa sobre interpretación y cumplimiento de contratos de obras públicas, adquisiciones, arrendamientos y servicios celebrados por las dependencias y entidades de la Administración Pública Federal.

En México, si bien existen figuras jurídicas (no jurisdiccionales) similares al contencioso de interpretación en la vía de recurso directo de interpretación, como son la consulta que se tramita ante la Procuraduría de la Defensa del Contribuyente y la también denominada consulta cuyo trámite se realiza ante el Servicio de Administración Tributaria. Lo resuelto en la primera solo refleja las opiniones de la citada Procuraduría en su carácter de órgano técnico especializado en materia tributaria, por lo que el dictamen que se emite en una consulta de esa naturaleza constituye una mera opinión técnica en materia fiscal, no vinculatoria para las autoridades fiscales. Por su parte, la segunda tiene el inconveniente de que cuando la respuesta dada por la autoridad fiscal a la consulta sea desfavorable al contribuyente, este solo podrá quejarse a través de los medios de defensa establecidos en las disposiciones aplicables una vez que la autoridad aplique el criterio (desfavorable) contenido en la contestación a la consulta de que se trate, en una resolución definitiva y, por tanto, produzca afectación a su esfera jurídica.

Por las razones anteriores, en el presente trabajo se reflexiona acerca de la conveniencia de la implementación en México del contencioso de interpretación en materia fiscal y administrativa, en la vía de recurso directo de interpretación, haciendo notar las ventajas y beneficios que dicho procedimiento proporcionaría a la justicia administrativa federal en México.

\section{El contencioso de interpretación}

\section{Concepto y origen}

En materia contencioso-administrativa, algunos países del mundo se han visto influenciados por el Derecho francés, tanto así que países como Venezuela, Panamá y México han adoptado en sus respectivos sistemas jurídicos el contencioso-administrativo tradicionalmente utilizado en Francia.

Fue Louis-Julien Édouard Laferrière -Vicepresidente del Consejo de Estado francés de 1886 a 1898-, en su obra titulada Traité de la juridiction administrative et des re- 
cours contentieux, cuya primera edición vio la luz en 1886, quien por primera vez estableció una clasificación de los tipos de contencioso-administrativo (el de anulación, el de plena jurisdicción, el de interpretación y el de represión) (Fernández Ruiz en González Martín, 2006, 166). Dicha clasificación continúa utilizándose hasta nuestros días “(...) a pesar de las críticas y los nuevos esquemas propuestos, como el del jurista René Chapus (...)". (http://www.viepublique.fr/decouverteinstitutions/institutions/ approfondissements/quatre-types contentieux-administratif.html. Consultado el 4 de febrero de 2015).

En el caso de diversos países latinoamericanos (incluido México), tanto su legislación como gran parte de su doctrina han dado más importancia al contencioso de anulación y al de plena jurisdicción, dejando de lado al denominado contencioso de interpretación, lo cual, desde nuestro punto de vista, obedece al escaso estudio que se le ha dedicado en esos países al contencioso de interpretación, no obstante que la mayoría de ellos, como ya se indicó, están influenciados por el sistema contencioso-administrativo francés.

El contencioso de interpretación es un tipo de contencioso-administrativo que " (...) puede interponerse, sea con ocasión al surgimiento de una cuestión prejudicial de tipo administrativo en una jurisdicción distinta de la contencioso-administrativa (prejudicialidad administrativa en un proceso ordinario, por ejemplo), sea en forma autónoma, como un recurso directo de interpretación de actos o contratos administrativos" ( Brewer-Carias y Pérez Olivares, 1965, pág. 111).

Algunos autores, como Abel Batista, consideran que los vocablos "contenciosoadministrativo de interpretación" no son coincidentes con la finalidad que se persi- gue con el mismo, puesto que se habla de "contencioso" cuando el procedimiento no está basado en un litigio o contienda (Batista Domínguez, 2007, pág. 57).

En otras palabras, el contencioso de interpretación

[C]omprende el recurso de interpretación en reenvío de tribunales judiciales en el que se invita a las partes para que se dirijan a un juez administrativo para solucionar una cuestión litigiosa en materia administrativa como acto prejudicial y el recurso directo de interpretación en el cual se solicita directamente a un juez administrativo la interpretación de un acto o de una resolución, ambos administrativos". (Márquez, 2002, pág. 150) Diverso punto de vista lo considera como " (...) el conjunto de reglas mediante las cuales se puede solicitar y obtener de la autoridad competente, la interpretación de los actos administrativos. (Altamira en Briseño, 1968, pág. 181).

El doctrinario venezolano Enrique Pérez Olivares entiende que el contencioso de interpretación es un medio procesal administrativo (del proceso contencioso-administrativo) en el cual una persona que está legitimada deduce una "pretensión merodeclarativa", es decir, solicita del órgano jurisdiccional que establezca cuál es el derecho aplicable al caso que está presentando (Pérez Olivares,1979, pág. 160).

Por su parte, el abogado panameño Sanjur Olmedo considera que el contencioso de interpretación es una vía jurídica a través de la cual una autoridad encargada de aplicar un acto administrativo de sentido oscuro o ambiguo solicita a la Tercera Sala de la Corte Suprema de Justicia que fije la recta interpretación del acto, explicando a la Sala 
las dificultades de interpretación que el acto plantea (Sanjur en Fábrega, 1990, pág. 321).

Como se observa de lo opinado por los doctrinarios en cita, dicho modelo de justicia administrativa (el contencioso de interpretación) comprende el recurso de interpretación en reenvío de tribunales judiciales y el recurso directo de interpretación, el primero se da cuando en un proceso que se tramita ante el Poder Judicial. Señala sobre el particular José Luis Vásquez:

(...) y toda vez que los tribunales judiciales no pueden interpretar, salvo casos excepcionales, el sentido de un acto administrativo, se plantea la necesidad de conocer el sentido de un acto administrativo a efecto de solucionar un litigio. Corresponde al tribunal judicial declararse en presencia de una cuestión prejudicial, fijar un plazo para resolver el fondo del asunto e invitar a las partes para que se dirijan a un juez administrativo con la finalidad de obtener la solución de una cuestión litigiosa (Vásquez Alfaro, 1991, pág. 55).

Doctrinarios como A-R. Brewer-Carias y Enrique Pérez Olivares denominan al recurso de interpretación en reenvío de tribunales judiciales recurso de interpretación con motivo de una cuestión prejudicial, y al respecto sostienen que este:

[o]pera cuando un tribunal judicial está obligado a suspender el proceso porque una cuestión de la competencia de la jurisdicción contencioso-administrativa, y que es decisiva para su decisión final, aparece en el curso del proceso. En estos casos, el juez contencioso-administrativo decide sobre la interpretación de un acto o contrato oscuro o sobre la apreciación de su legali- dad, cuando se le pide decidir si el acto que alguna de las partes tacha de ilegal, es o no legal. En estos casos, el juez de la jurisdicción ordinaria decidirá el litigio para el cual es competente, basándose en la interpretación o la apreciación de la legalidad que haga el juez contencioso-administrativo (Brewer-Carias y Pérez Olivares, 1965, pág. 114).

En tanto que el recurso directo de interpretación tiene por objeto pedir directamente al juez una declaración sobre la interpretación que deba dársele a un acto o contrato administrativo oscuro (Brewer-Carias, y Pérez Olivares, 1965, 114). Esto es, se pide al juez administrativo la interpretación de un acto o de una resolución de carácter administrativo, cuyo sentido y alcance resultare oscuro, ambiguo o confuso, a efecto de que el órgano jurisdiccional determine la correcta interpretación del mismo. Por lo que la interpretación está cercana a la consulta, puesto que se exige del juez realizar una labor de investigación de la regla del derecho, señalando el sentido de un acto o de un contrato administrativo que adolece de oscuridad (Briseño Sierra, 1968, pág. 181).

Es preciso señalar que, en el caso del recurso directo de interpretación, si bien la mayoría de los autores coincide en que esa vía de contencioso de interpretación recae únicamente sobre la inteligencia de actos o contratos administrativos cuyo sentido y alcance resultare oscuro, debe decirse que la jurisdicción contencioso-administrativa venezolana admite una forma distinta del recurso directo de interpretación en cuanto a su objeto por cuanto que, en el numeral 6 del artículo 266 de la Constitución de la República Bolivariana de Venezuela, se señala la facultad del Tribunal Supremo de Justicia 
para conocer de los recursos de interpretación sobre el contenido y alcance de los textos legales, en los términos contemplados en la ley, recayendo esa atribución (de conformidad con la Ley Orgánica del Tribunal Supremo de Justicia, publicada en la Gaceta Oficial de la República Bolivariana de Venezuela $n .^{\circ} 39.522$ del $1^{\circ}$ de octubre de 2010), en Sala Político-Administrativa del aludido Tribunal, la cual cuenta con competencia para conocer de los recursos de interpretación de leyes de contenido administrativo.

Conviene señalar que, en el ámbito internacional, países como Francia -donde tiene su origen el contencioso de interpretación, específicamente en el Consejo de Estado-, Panamá y Venezuela, desde hace ya varios años, adoptaron en su sistema jurídico dicho modelo de justicia administrativa, en cualquiera de sus vías o formas -sea como recurso de interpretación con motivo de una cuestión prejudicial o como un recurso directo de interpretación-.

El contencioso de interpretación es una de las tareas que tiene el Consejo de Estado; es una forma de ahorrar espacios procesales por cuestión de economía procesal y rapidez en aquel que comprende el recurso de interpretación en reenvío de tribunales judiciales. En él se invita a las partes de un litigio para que acudan a un juez administrativo a efectos de solucionar una cuestión en materia administrativa. Es decir, se le denominaría como un acto pre-judicial en el que el recurso directo de interpretación se solicita directamente a un juez en materia administrativa la interpretación de un acto o de una resolución de carácter administrativo (Arreola Talavera en Revista digital Praxis de la justiticia fiscal y administrativa, 2013, pág. 13).

En la presente investigación, la vía de contencioso de interpretación que proponemos es precisamente la relativa al recurso directo de interpretación en términos similares al contemplado en la legislación venezolana y el cual será analizado más adelante. En otras palabras, proponemos que el contenciosoadministrativo federal en México adopte en su legislación el recurso directo de interpretación, a través del cual el órgano jurisdiccional competente para conocer del mismo decida, previa consulta de interpretación realizada por quien esté legalmente facultado para ello. Se busca darle el alcance o la inteligencia debida a textos legales de índole fiscal y administrativo, ello a través de un procedimiento original, sencillo, ágil y eficaz desarrollado en el presente estudio.

Los beneficios que traería consigo la implementación en México de ese modelo de justicia administrativa serían notables, puesto que, al ser un procedimiento con las aludidas características, serviría para hacer frente al rezago jurisdiccional que agobia al Tribunal Federal de Justicia Fiscal y Administrativa y, con ello, se respetaría en beneficio de los justiciables el derecho fundamental previsto en el artículo 17 de la Constitución General de la República, así como el derecho de la tutela judicial efectiva establecido en los artículos 8 y 25 de la Convención Americana sobre Derechos Humanos.

Adicionalmente a ello, con la decisión que adopte el órgano jurisdiccional competente que conozca del recurso directo de interpretación, se otorgaría certeza jurídica al particular en su relación con las autoridades fiscales y administrativas federales, al quedar definido el sentido, alcance o la inteligencia que debe dársele a textos legales de índole fiscal y administrativa cuando estos resultaren oscuros, ambiguos o confusos. Asimismo, la adopción en el sistema jurídico mexicano de un procedimiento como el que 
nos ocupa permitiría la unificación de criterios sobre la interpretación de leyes fiscales y administrativas, con lo que se preserva la uniformidad de la interpretación legal y se garantiza la seguridad jurídica del particular.

\section{Naturaleza jurídica y objeto}

Existe consenso por parte de los doctrinarios, principalmente venezolanos y panameños, en que el contencioso de interpretación -también denominado, como ya se ha visto, recurso de interpretación o acción de interpretación- (Batista Domínguez, 1957, pág. 61), es de naturaleza declarativa, merodeclarativa o de mera certeza; (Brewer-Carias y Pérez Olivares, 1965, pág. 108) justifican esa naturaleza en el objeto mismo de la acción, a saber, la solicitud directa al juez de una declaración acerca de las interpretaciones que le merecen, tantos los actos que se dicten en aplicación de la ley, como las propias normas que conforman el articulado" (Pérez Salazar, 2001, pág. 221).

Respecto de la naturaleza declarativa del contencioso de interpretación, el máximo tribunal contencioso-administrativo panameño ha sostenido lo siguiente:

En cuanto a la petición de interpretación, no cabe duda que está ante una pretensión declarativa. El tratadista Jaime Guasp ha señalado que "cuando lo que se solicita del órgano competente es la simple declaración de una simple situación jurídica que existía con anterioridad a la decisión buscando su sola certeza la pretensión recibe el nombre de declarativa" y agrega que "la petición de la parte que la constituye tiende a la mera constatación, fijación o expresión judicial de una situación jurídica ya existente". Sobre este mismo tema Eduardo Couture señala que "son sentencias declarativas o de mera declaración aquellas que tienen por objeto la pura declaración de la existencia de un derecho" (Batista Domínguez, 1957, pág. 54) (Sentencia Corte Suprema de Justicia de Panamá).

En palabras del distinguido jurista venezolano Allan-Randolph Brewer Carias, las acciones merodeclarativas están

(...) dirigidas a la simple constatación de un estado de hecho o de derecho y que tienen como fin eliminar la incertidumbre o la falta de acuerdo en torno al mismo y de obtener una prueba pública e irrefutable de la situación, siendo ellas también admitidas generalmente por la doctrina administrativa. (...) En materia administrativa, en efecto, se suele destacar que el administrado tiene con frecuencia interés de obtener ese tipo de declaración, sin necesidad de tener que pedir también al juez, que condene a la Administración a reparar un daño causado por la lesión que puede haberse producido, y que resulte evidenciado del pronunciamiento merodeclarativo; interés que existe en diversos casos y por diversas razones, sobre todo cuando se pretende que la Administración se abstenga de hacer algo en forma específica, para evitar así tener que acudir al ejercicio de acciones de condena (Brewer Carias, y Pérez Olivares, 1965, pág. 06).

Para el doctrinario, también venezolano, Pedro Manuel Arcaya, la acción de mera declaración es aquella por la cual se pide el aseguramiento de un derecho por decisión judicial y respecto a cuyo derecho hay un estado de falta de certeza o de discusión que se refiere a las obligaciones de las partes. En las acciones de este tipo no se pide prestación o derecho alguno, sino el reconocimiento de un 
derecho respecto al cual hay discusión o inseguridad (Arcaya en Revista de la Facultad de Derecho U. de Venezuela, 1957, pág. 80).

En resumen, podemos considerar que las acciones declarativas son aquellas a través de las cuales se pide a un órgano jurisdiccional que declare la existencia de un derecho, cuando exista respecto de este un estado de duda o incertidumbre acerca de su existencia, por lo que la sentencia que se dicte en este tipo de asuntos en modo alguno será condenatoria. En otras palabras, mediante ese tipo de acciones, lo que se pide al juez no es una sentencia de condena o que resuelva sobre una prestación, sino que clarifique la existencia de un derecho.

Por cuanto hace al objeto del contencioso de interpretación, podemos decir que este dependerá en gran medida del sistema jurídico en el que se encuentre regulado. Esto se afirma así en razón a que, por ejemplo, en el caso venezolano, dicha institución jurídica en la forma en que actualmente está prevista, como ya lo hemos visto, tiene como objeto o propósito indagar o esclarecer el sentido de textos legales, esto es, la interpretación que se solicite mediante el recurso de interpretación debe versar sobre un texto legal. En cambio, en el caso panameño, el contencioso de interpretación tiene como objeto pronunciarse prejudicialmente acerca del sentido y alcance de un acto administrativo o de su valor legal (Batista Domínguez, 1957, pág. 53). Debe tratarse de un acto administrativo confuso u oscuro o de dudosa interpretación.

Como se observa, tratándose de esos países, el objeto del contencioso de interpretación es totalmente distinto, puesto que, en el caso de Venezuela, la interpretación recae sobre textos legales, mientras que en el caso de Panamá, la interpretación se realiza sobre actos administrativos.

\section{Notas generales del recurso de interpretación en Venezuela}

Los orígenes del recurso de interpretación en la República de Venezuela se remontan al año 1976 y, desde ese año hasta la fecha, dicha institución procesal ha ido evolucionando. En un primer término, la jurisprudencia entendió que dicho recurso de interpretación solo podía ser ejercido cuando la ley cuya interpretación se solicitaba así lo permitía. Asimismo, de acuerdo con la Ley Orgánica de la Corte Suprema de Justicia, la Sala PolíticoAdministrativa era la única competente para conocer de este tipo de recursos. Con ocasión de la nueva Constitución de 1999, la jurisprudencia, tanto de la Sala Político-Administrativa como de la Sala Constitucional, ha precisado que el recurso de interpretación debe versar sobre un texto normativo -bien legal o sublegal-, aun cuando el mismo no establezca expresamente la posibilidad de interpretarse y exigiendo, además, que el recurso de interpretación no persiga sustituir los recursos procesales existentes u obtener una declaratoria con carácter de condena o constitutiva y que sea conocido por la Sala del Tribunal Supremo de Justicia cuya competencia sea afín con la materia del caso concreto (Escudero León, 2005, p. 255).

De lo transcrito con antelación, se observa que de acuerdo con la Ley Orgánica de la otrora Corte Suprema de Justicia de Venezuela, la Sala Político-Administrativa era la única competente para conocer del recurso de interpretación. En la actualidad, conforme a lo previsto en la Ley Orgánica del Tribunal Supremo de Justicia de la República Bolivariana de Venezuela, 
se denomina Tribunal Supremo de Justicia, constituye parte del Sistema de Justicia Venezolano y es el máximo órgano y rector del Poder Judicial, funciona en Sala Constitucional, Político-Administrativa, Electoral, de Casación Civil, de Casación Penal y de Casación Social, así como por la Sala Plena que está integrada por los Magistrados o Magistradas de todas las Salas señaladas.

De esta manera, el numeral 24 del artículo 42 , en relación con el artículo 43 de la derogada Ley Orgánica de la Corte Suprema de Justicia, disponía que correspondía a la Sala Político-Administrativa la competencia para conocer de los recursos de interpretación y de las consultas que se le formularan sobre el alcance e inteligencia de los textos legales, de conformidad con los casos previstos en la ley.

Posteriormente, con la entrada en vigor de la Constitución venezolana de 1999, se creó el Tribunal Supremo de Justicia y las nuevas Salas que lo integran. Según se desprende del artículo 262 de dicha Ley Suprema, se otorgan expresamente ciertas competencias a sus distintas Salas, las cuales se obligaban a conocer y decidir todos aquellos asuntos que se encontraran en trámite ante la extinta Corte Suprema de Justicia, así como aquellos que ingresaran atendiendo a la afinidad existente entre la materia debatida en el caso concreto y la especialidad de cada una de las Salas (Sentencia Sala Político-Administrativa -0001-2000).

Hoy en día, en el numeral 6 del artículo 266 de la Constitución de la República Bolivariana de Venezuela, se contempla expresamente la atribución del Tribunal Supremo de Justicia para conocer de los recursos de interpretación sobre el contenido y alcance de los textos legales, en los términos contemplados en la ley; sin que dicho precepto prevea a cuál Sala del aludido Tribunal corresponde el conocimiento del recurso de marras, limitándose únicamente a expresar que las demás atribuciones serán ejercidas por las diversas Salas conforme a lo previsto en la Constitución y en la ley.

No obstante ello, el Tribunal Supremo de Justicia, específicamente la Sala Constitucional y la Sala Político-Administrativa, de acuerdo con lo previsto en el numeral 6 del artículo 266 de la Constitución de la República Bolivariana de Venezuela, en concordancia con el artículo 262 eiusdem, a través de su jurisprudencia han venido expresando:

[C]omo quiera que la creación de nuevas Salas es reveladora del ánimo de especializar sus funciones con respecto a las áreas que constituyen su ámbito de competencia, debe entenderse que la intención del constituyente es que dicho mecanismo, dirigido a resolver las consultas que se formulen acerca del alcance e inteligencia de los textos legales, lo conozca y resuelva la Sala cuya competencia sea afín con la materia del caso concreto.

En ese sentido, con independencia de que la Constitución de Venezuela no prevea a cuál de las Salas -Constitucional, PolíticoAdministrativa, Electoral, de Casación Civil, de Casación Penal y de Casación Social y Sala Plena- que componen el Tribunal Supremo de Justicia de ese país corresponde el conocimiento del recurso de interpretación, la Ley Orgánica del Tribunal Supremo de Justicia sí lo hace, puesto que, en el artículo 31 , numeral 5 de dicho ordenamiento legal, se señala que la competencia para conocer del recurso de interpretación es común a todas las Salas que integran dicho Tribunal. Cabe precisar que la Ley Orgánica del 
Tribunal Supremo de Justicia (2004) sufrió una reforma en el año 2010, y aunque sigue aplicando supletoriamente a la jurisdicción contencioso-administrativa cuya cúspide es la Sala Político-Administrativa. En la actualidad, dicha Sala y los órganos que integran la jurisdicción están regulados inicialmente por la Ley Orgánica de la Jurisdicción Contencioso-Administrativa.

Ciertamente, el artículo 31, numeral 5, del invocado cuerpo de leyes, dispone:

Son competencias comunes de cada Sala del Tribunal Supremo de Justicia:

(...omissis...)

5. Conocer las demandas de interpretación acerca del alcance e inteligencia de los textos legales, siempre que dicho conocimiento no signifique una sustitución del mecanismo, medio o recurso que disponga la ley para dirimir la situación de que se trate.

(...omissis...).

Empero, en lo atinente a los recursos de interpretación de leyes de contenido administrativo, el artículo 26, numeral 21, de la Ley Orgánica del Tribunal Supremo de Justicia confiere claramente el conocimiento de los mismos a la Sala Político-Administrativa del aludido Tribunal, circunstancia que encuentra respaldo en lo dispuesto en los artículos 9, numeral 6, y 23, numeral 21, de la Ley Orgánica de la Jurisdicción ContenciosoAdministrativa.

En relación con la admisibilidad del recurso de interpretación, debe decirse que quien pretenda interponerlo deberá cumplir con los siguientes requisitos, a saber:

- Que la interpretación que se solicite verse sobre un texto legal.
- Que dicho conocimiento no signifique una sustitución del mecanismo, medio o recurso previsto en la ley para dirimir la situación si la hubiere.

Es necesario señalar que, si bien la legislación venezolana no prevé otro tipo de requisitos para la formulación de un recurso de interpretación, ello no ha impedido que el Tribunal Supremo de Justicia de ese país, a través de la jurisprudencia, haya desarrollado otras exigencias que se deben cumplir para su admisión y tramitación, a saber:

Establecer la conexidad con un caso concreto, para determinar la legitimidad del recurrente y la existencia de una duda razonable sobre la inteligencia de la disposición legal.

- Que la interpretación solicitada verse sobre un texto legal o constitucional, aun cuando el mismo no establezca expresamente la posibilidad de interpretarse.

- Que se precise en qué consiste el motivo de la interpretación.

- Que la Sala no se haya pronunciado con anterioridad sobre el punto requerido $\mathrm{y}$, en tal caso, que no sea necesario modificar el criterio sostenido.

- Que el recurso de interpretación no persiga sustituir los recursos procesales existentes ni obtener una declaratoria con carácter de condena o constitutiva.

- Que no se acumule a la pretensión otro recurso o acción de naturaleza diferente, $o$ acciones incompatibles, excluyentes o contradictorias.

- Que el objeto de la interpretación no sea obtener una opinión previa del órgano jurisdiccional para la solución de un caso concreto que esté siendo conocido por otro órgano jurisdiccional, bien sea entre particulares o entre estos y los órganos públicos (Sentencia Sala Político-Administrativa 0282 de 2010). 
De no cumplirse cualquiera de los anteriores requisitos, se considerará inadmisible el recurso de interpretación, a menos que la interpretación se solicite respecto de diversos textos legales, caso en el cual se considerará inadmisible dicho recurso solo en lo relativo a la disposición que no cumpla con las anteriores exigencias.

A continuación, comentamos brevemente algunos de los referidos requisitos que en nuestra opinión tienen mayor importancia.

El primero de los requisitos se refiere a la legitimación del interesado y a la necesidad de que la solicitud de interpretación se refiera a un caso concreto (...) al cual debe circunscribirse la labor interpretativa, con lo que se persigue evitar el mero ejercicio académico de este particular mecanismo, restringiéndolo a aquellos casos en que esté demostrada la existencia de un interés jurídico que, en criterio de la Sala, ha de ser personal y directo. Para promover la acción de interpretación de normas se requiere un interés procesal legítimo, es decir, que cualquier persona natural o jurídica puede interponer este tipo de procesos, incluso autoridades (Sentencia Sala Político-Administrativa 0282 de 2010).

Por lo que hace al segundo requisito, relativo a que la interpretación solicitada sea de un texto legal (aun cuando el mismo no establezca expresamente la posibilidad de interpretación de sus normas), cabe traer a colación lo resuelto en la sentencia 22 de marzo de 2007, dictada en el expediente $n$. $^{\circ}$ 00493 por la Sala Político-Administrativa del Tribunal Supremo de Justicia de la República Bolivariana de Venezuela, que a la letra dice:

De lo antes indicado, se concluye que tanto el texto constitucional, la Ley que rige las funciones de este Alto Tribunal y la jurisprudencia de esta Sala, han previsto expre- samente la posibilidad de que la acción de interpretación sea solo sobre normas de rango legal (entre los que se encuentran los Decretos-Leyes), es decir, aquellas dictadas conforme a la Constitución, por lo que al ser el Reglamento una norma de rango sublegal, esto es, una norma secundaria complementaria de la ley, considera la Sala que el mismo no puede ser objeto de la acción de interpretación.

De lo anterior se sigue que la petición de interpretación solo puede versar sobre normas de rango legal (entre las que se encuentran los Decretos-Leyes), lo que excluye cualquier tipo de interpretación sobre normas de rango sub-legal, como pudieran ser los reglamentos, acuerdos y resoluciones. $\mathrm{La}$ razón de ello obedece a que dichas normas (de rango sub-legal) no son sancionadas por la Asamblea Nacional Venezolana como cuerpo legislador, conforme lo prevé el artículo 202 de la Constitución de la República Bolivariana de Venezuela, ni se trata de un Decreto Ley, una ley estatal o una ordenanza (leyes municipales), los cuales sí pueden ser objeto de dicha acción de interpretación.

No obstante, debe decirse que el recurso de interpretación es posible formularlo respecto de normas constitucionales, por lo menos ante la Sala Constitucional. Así lo informa la sentencia dictada por esa Sala el 21 de noviembre de 2000 , en la que se expresó:

[1]a interpretación del contenido y alcance de las propias normas y principios constitucionales es posible, tal como lo expresa el artículo 335 de la Constitución de la República Bolivariana de Venezuela, en concordancia con el artículo 336, y por ello, el recurso de interpretación puede estar dirigido, al menos ante esta Sala, a la in- 
terpretación constitucional, a pesar que el recurso de interpretación, al ser considerado tanto en la propia Constitución (artículo 266 numeral 6), como en la Ley Orgánica de la Corte Suprema de Justicia (numeral 24 del artículo 42) se refieren al contenido y alcance de los textos legales, en los términos contemplados en la ley.

Esto se respalda con lo previsto en la reforma de 2010 que sufrió la Ley Orgánica del Tribunal Supremo de Justicia, en la cual se incluyeron algunos procesos constitucionales tramitados ante la Sala Constitucional. Entre ellos, el consagrado en los artículos 128 y siguientes de la citada ley, que se aplica al recurso de interpretación de normas y principios constitucionales.

También en relación con el segundo de los requisitos que se comenta, importa decir que, según lo ha establecido el Alto Tribunal del Estado Venezolano, las normas de carácter procesal tampoco son susceptibles de ser interpretadas a través del recurso de interpretación, dado que dichas normas únicamente son interpretadas por el juzgador con ocasión de la conducción del proceso y su decisión (Sentencia Sala de Casación Civil n. ${ }^{\circ}$ 000700-2007).

El tercero de los requisitos indica que debe señalarse con precisión en qué consiste el motivo de la petición de interpretación, siendo su razón principal la obtención de la interpretación por parte del órgano jurisdiccional de una norma legal que plantee oscuridad o duda y, por lo cual, es necesaria la aclaración sobre el significado y alcance de dicha norma.

El quinto requisito se refiere a que el recurso de interpretación no signifique la sustitución del medio o recurso previsto en la ley para dirimir la situación sometida a interpre- tación, o la obtención de una declaratoria con carácter de condena o constitutiva. Ejemplo de ello se da cuando el peticionario de la interpretación la formula no solo para esclarecer el alcance de las normas legales, sino también con el fin de, posteriormente, presentar una reclamación en sede administrativa con base en la declaratoria que emita el órgano jurisdiccional que decida el aludido recurso de interpretación (Sentencia Sala Político-Administrativa 2011-0178-2013).

Finalmente, respecto al último de los requisitos, relativo a que el objeto de la interpretación legal no sea obtener una opinión previa del órgano jurisdiccional para la solución de un posterior conflicto, bien sea entre particulares o entre estos y los órganos públicos. La Sala Político-Administrativa del Tribunal Supremo de Justicia explica que ello consiste en que la pretensión del solicitante no revista un carácter constitutivo, esto es, obtener una opinión previa del órgano jurisdiccional que genere derechos a favor del peticionario de interpretación.

Para tramitar el referido recurso de interpretación, se sigue el procedimiento común a las demandas de nulidad, interpretación y controversias administrativas, previsto en el artículo 76 y siguientes de la Ley Orgánica de la Jurisdicción Contencioso-Administrativa. Dicho procedimiento se desarrolla de la siguiente manera:

1. Recepción de la demanda. Recibida la demanda o solicitud de interpretación, el Tribunal se pronuncia sobre su admisibilidad dentro de los tres días de despacho siguientes a su recepción.

2. Notificación. Admitida la demanda, se ordena la notificación de las siguientes personas y autoridades:

- En los casos de recursos de nulidad, al representante del órgano que haya dic- 
tado el acto; en los casos de recursos de interpretación, al órgano del cual emanó el instrumento legislativo; y en los de controversias administrativas, al órgano o ente contra quien se proponga la demanda.

- Al Procurador General de la República y al Fiscal General de la Republica.

- A cualquier otra persona, órgano o ente que deba ser llamado porque así lo disponga la ley o cuando así lo determine el Tribunal.

- Las notificaciones correspondientes se harán mediante oficio que será entregado por el alguacil (notificador) en la oficina receptora de correspondencia de que se trate. El alguacil levantará constancia de haber notificado y de los datos de identificación de la persona que recibió el oficio.

3. Expediente administrativo. Con la notificación se ordena el envío del expediente administrativo o de los antecedentes correspondientes, lo que deberá acontecer dentro de los diez días hábiles siguientes. El servidor público que omita o retarde dicha remisión podrá ser sancionado por el tribunal con multa entre cincuenta unidades tributarias (50 U.T.) y cien unidades tributarias (100 U.T.).

4. Cartel de emplazamiento. Admitida la demanda, se ordena la notificación a los interesados a través de un cartel (notificación en prensa) que se publica en el diario que designe el Tribunal, a efectos de que comparezcan al juicio y se informen de la audiencia del mismo.

5. Lapso para retirar, publicar y consignar el cartel. El demandante tiene la obligación de retirar el cartel de emplazamiento dentro de los tres días de despacho siguientes a su emisión, lo publicará y consignará la publicación, dentro de los ocho días de despacho siguientes a su retiro.

El incumplimiento de la obligación anterior tiene como consecuencia que el Tri- bunal declare el desistimiento del recurso y ordene el archivo del expediente, a menos que dentro del plazo señalado algún interesado se diera por notificado y consignara su publicación.

6. Audiencia del juicio. Una vez realizadas las notificaciones correspondientes y que obre en autos la publicación del cartel de emplazamiento, el Tribunal, dentro de los cinco días siguientes, señalará fecha para la audiencia del juicio, a la cual deberán acudir las partes y los interesados. Dicha audiencia será celebrada dentro de los veinte días de despacho siguientes. En caso de que el demandante no asista a la audiencia, se le tendrá por desistido del procedimiento. En los tribunales colegiados, en esta misma oportunidad, se designará ponente.

7. Contenido de la audiencia. Al inicio de la audiencia, el Tribunal hará del conocimiento de las partes y demás interesados el tiempo de que disponen para formular sus exposiciones orales, las cuales, además, deberán presentarse por escrito. Dentro de ese mismo tiempo, las partes podrán presentar sus medios probatorios.

8. Lapso de pruebas. Dentro de los tres días siguientes a la celebración de la audiencia, el Tribunal admitirá las pruebas, salvo que sean ilegales, impertinentes o inconducentes y ordenará el desahogo de las que lo requieran, para lo cual se contará con diez días prorrogables hasta por diez días más.

9. Informes. Dentro de los cinco días siguientes al vencimiento del desahogo de pruebas, si lo hubiere, o dentro de los cinco días siguientes a la celebración de la audiencia, en los casos en que no se hayan presentado pruebas o las presentadas no hubieran requerido de desahogo, se presentarán los informes por escrito o de manera oral si alguna de las partes lo solicita. 
10. Dictado de la sentencia y apelación. Vencido el plazo para presentar los informes, el Tribunal dictará sentencia dentro de los treinta días siguientes. El dictado de la sentencia podrá diferirse por un plazo igual siempre y cuando exista causa que lo justifique. La sentencia que se emita fuera del plazo señalado deberá ser notificada, sin lo cual no correrá el plazo para interponer los recursos. La sentencia definitiva podrá ser apelada por las partes dentro de los cinco días siguientes a su publicación.

\section{Figuras jurídicas no jurisdiccionales en México similares al contencioso de interpretación en la vía de recurso directo de interpretación}

Inicialmente, es preciso señalar que en la jurisdicción contencioso-administrativa federal mexicana, la única aproximación al contencioso de interpretación en la vía de referencia, la encontramos en la Ley Orgánica del Tribunal Federal de Justicia Fiscal y Administrativa, específicamente en la fracción VII del artículo 14, que dispone:

El Tribunal Federal de Justicia Fiscal y Administrativa conocerá de los juicios que se promuevan contra las resoluciones definitivas, actos administrativos y procedimientos que se indican a continuación: VII. Las que se dicten en materia administrativa sobre interpretación y cumplimiento de contratos de obras públicas, adquisiciones, arrendamientos y servicios celebrados por las dependencias y entidades de la Administración Pública Federal.

Sin embargo, en el ámbito no jurisdiccional, existen en nuestro país figuras jurídicas que guardan similitud con el contencioso de interpretación (en la vía de recurso directo de interpretación). Entre ellas, podemos encontrar la consulta que se tramita ante la Procuraduría de la Defensa del Contribuyente y la también denominada consulta cuyo trámite se realiza ante el Servicio de Administración Tributaria, y de las que hablaremos en los párrafos siguientes.

\section{La consulta ante la Procuraduría de la Defensa del Contribuyente}

La Procuraduría de la Defensa del Contribuyente es un órgano del Estado Mexicano de reciente creación; apenas el $1^{\circ}$ de septiembre de 2011 abrió sus puertas al público en general. Normativamente, su existencia se encuentra prevista en el artículo 18-B del Código Fiscal de la Federación, que dispone que

La protección y defensa de los derechos e intereses de los contribuyentes en materia fiscal y administrativa, estará a cargo de la Procuraduría de la Defensa del Contribuyente, correspondiéndole la asesoría, representación y defensa de los contribuyentes que soliciten su intervención, en todo tipo de asuntos emitidos por autoridades administrativas y organismos federales descentralizados, así como, determinaciones de autoridades fiscales y de organismos fiscales autónomos de orden federal.

Dicha Procuraduría es un organismo público descentralizado, no sectorizado, con autonomía técnica funcional y de gestión, especializado en materia tributaria, que proporciona de forma gratuita, ágil y sencilla servicios de asesoría y consulta, defensoría y representación, y da seguimiento a los procedimientos de queja o reclamación contra ac- 
tos de las autoridades fiscales federales que vulneren los derechos de los contribuyentes.

La Procuraduría de la Defensa del Contribuyente es un verdadero Ombudsman Fiscal, el primero en México, cuya misión es garantizar el derecho de los contribuyentes a recibir justicia en materia fiscal en el orden federal, a través de la prestación de los servicios gratuitos de asesoría, representación y defensa, velando por el cumplimiento efectivo de sus derechos, para contribuir a propiciar un ambiente favorable en la construcción de una cultura de plena vigencia de los derechos del contribuyente. También se encarga de la recepción de quejas, reclamaciones o emisión de recomendaciones públicas a las autoridades fiscales federales, a efecto de que se lleguen a corregir aquellas prácticas que indebidamente lesionan o les causan molestias excesivas o innecesarias a los contribuyentes.

Dentro de las facultades más relevantes del referido Ombudsman Fiscal mexicano, las cuales se encuentran previstas en el artículo 5 de la Ley Orgánica de la Procuraduría de la Defensa del Contribuyente, podemos enunciar las siguientes:

a. Atender y resolver las solicitudes de asesoría y consulta que le presenten los contribuyentes por actos de las autoridades fiscales federales;

b. Representar al contribuyente ante la autoridad correspondiente, promoviendo a su nombre los recursos administrativos procedentes y en su caso ante el Tribunal Federal de Justicia Fiscal y Administrativa, ejerciendo las acciones a que haya lugar, deduciendo con oportunidad y eficacia los derechos de sus representados, hasta su total resolución;

c. Conocer e investigar de las quejas de los contribuyentes afectados por los actos de las autoridades fiscales federales por presuntas violaciones a sus derechos, en los términos de la citada Ley y, en su caso, formular recomendaciones públicas no vinculatorias, respecto a la legalidad de los actos de dichas autoridades;

d. Imponer las multas en los supuestos y montos que la Ley establece;

e. Recabar y analizar la información necesaria sobre las quejas y reclamaciones interpuestas, con el propósito de verificar que la actuación de la autoridad fiscal esté apegada a Derecho a fin de proponer, en su caso, la recomendación o adopción de las medidas correctivas necesarias, así como denunciar ante las autoridades competentes la posible comisión de delitos o actos que puedan dar lugar a responsabilidad civil o administrativa de las autoridades fiscales federales;

f. Proponer al Servicio de Administración Tributaria las modificaciones normativas internas para mejorar la defensa de los derechos y seguridad jurídica de los contribuyentes;

g. Identificar los problemas de carácter sistémico que ocasionen perjuicios a los contribuyentes, a efecto de proponer al Servicio de Administración Tributaria las recomendaciones correspondientes;

h. Emitir opinión sobre la interpretación de las disposiciones fiscales y aduaneras cuando así se lo solicite el Servicio de Administración Tributaria;

i. Convocar y realizar reuniones periódicas con las autoridades fiscales federales, quienes estarán obligadas a participar, cuando así se los solicite la Procuraduría en las reuniones que al efecto se programen, para formularle sugerencias respecto de sus actividades, así como de advertir o prevenir la comisión de cualquier acto ilegal en perjuicio de una persona o grupo de personas, o de proponerles que se eviten perjuicios o se reparen los 
daños causados a estos con su ilegal emisión, o por cualquier causa que la justifique;

j. Proponer a la Comisión de Hacienda y Crédito Público de la Cámara de Diputados modificaciones a las disposiciones fiscales.

Como se observa, la Procuraduría de la Defensa del Contribuyente cuenta entre sus facultades con la relativa a la atención y resolución de las solicitudes de consulta que le presenten los contribuyentes por actos de las autoridades fiscales federales.

De conformidad con lo dispuesto en el artículo 50 de los lineamientos que regulan el ejercicio de las atribuciones sustantivas de la Procuraduría de la Defensa del Contribuyente, las consultas que presenten los contribuyentes deberán cumplir con los siguientes requisitos:

- Estar formuladas por escrito;

- Señalar el nombre o denominación social de quien solicita la consulta, domicilio para recibir notificaciones, en su caso, el número telefónico y la dirección de correo electrónico para los mismos efectos;

- Expresar el acto o actos de autoridades fiscales que motivan la consulta, y los motivos que la originan, la materia de la misma y el planteamiento específico.

Aprovechando el uso de las tecnologías de la información, los referidos lineamientos establecen la posibilidad de que las consultas sean enviadas por los medios electrónicos con que cuente la Procuraduría de la Defensa del Contribuyente; para ello, el envío deberá ser en forma digitalizada cumpliendo con los requisitos antes mencionados y deberá contener, además, la firma del contribuyente o su representante legal, adjuntándose la respectiva identificación oficial vigente, y en su caso el instrumento legal que acredite su personalidad, así como los demás documentos que a su juicio sean necesarios para la solución de la consulta.

Para el caso anterior, el solicitante o su representante legal debe manifestar su imposibilidad para acudir personalmente a la Procuraduría de la Defensa del Contribuyente y señalar en el correo electrónico que envíe, bajo protesta de decir verdad, que la firma que aparece en la solicitud de consulta es suya.

Cuando el libelo de consulta no reúna los requisitos señalados, se requerirá al solicitante, por una sola vez, que los cumpla en el plazo de cinco días hábiles contados a partir de la notificación del requerimiento. Transcurrido el plazo sin que se cumpla con lo requerido, la consulta será resuelta con las constancias que obren en el expediente.

Conviene señalar que, tratándose de consultas en las que los contribuyentes manifiesten que no existe acto de autoridad fiscal, la Procuraduría las resolverá con fundamento en el artículo 8 de la Constitución Política de los Estados Unidos Mexicanos, en los términos de su competencia material; esto es, como si se tratara del ejercicio del derecho de petición que consagra dicho precepto constitucional.

En los casos en los que exista complejidad, necesidad técnica o razones determinadas que puedan apreciarse circunstancialmente en alguna consulta, la Procuraduría de la Defensa del Contribuyente podrá, discrecionalmente, requerir al particular para que cumpla con uno o varios de los requisitos a que alude el artículo 18-A del Código Fiscal de la Federación.

La consulta se entiende iniciada cuando se recibe el escrito relativo o cuando se cumplimenta el requerimiento antes señalado, y concluye cuando se emite el dictamen correspondiente, lo que deberá suceder en 
un plazo no mayor de treinta días hábiles contados a partir del siguiente a la fecha de presentación de la consulta, a menos que se trate de una consulta compleja, caso en el cual el plazo podrá duplicarse.

Emitido el dictamen se notificará al solicitante a más tardar al día hábil siguiente en el domicilio que haya señalado para recibir notificaciones o en el correo electrónico que hubiera señalado para tal efecto.

Es importante destacar que aunque en el escrito de consulta es requisito expresar el acto o actos de autoridades fiscales que la motivan, esta solo podrá versar sobre interpretaciones normativas de disposiciones fiscales o aduaneras que estén involucradas en el acto de autoridad materia de la consulta, sin que la Procuraduría de la Defensa del Contribuyente pueda pronunciarse respecto al reconocimiento de un derecho subjetivo o la declaratoria de ilegalidad o inconstitucionalidad del acto materia de la consulta.

En efecto, en tratándose de la consulta, la Procuraduría de la Defensa del Contribuyente no está facultada por la legislación que regula su actuar para pronunciarse respecto al reconocimiento de un derecho subjetivo o la declaratoria de ilegalidad o inconstitucionalidad del acto materia de la consulta; además de que, en congruencia con lo establecido en el artículo 55 de los Lineamientos que regulan el ejercicio de las atribuciones sustantivas de la Procuraduría de la Defensa del Contribuyente, lo resuelto en las consultas solo refleja las opiniones de la Procuraduría en su carácter de órgano técnico especializado en materia tributaria. Por lo anterior podríamos afirmar que el dictamen que se emite en una consulta constituye una mera opinión técnica en materia fiscal, no vinculatoria para las autoridades fiscales involucradas en la consulta.
No obstante lo anterior, en la práctica, diversos particulares que se encuentran en un litigio fiscal pendiente de resolución ante los tribunales federales han optado por el trámite de este especial mecanismo legal, a efectos de obtener la opinión de la Procuraduría de la Defensa del Contribuyente respecto de la interpretación normativa de disposiciones fiscales o aduaneras. Posteriormente la ofrecen como prueba en el juicio correspondiente. Ello en razón de que no existe prohibición legal para que los particulares acudan en consulta ante dicha Procuraduría, respecto de un acto de autoridad que sea objeto de un medio de defensa que se encuentre pendiente de resolución por el órgano competente, como así se prevé en el artículo 54 de los Lineamientos de marras.

De los párrafos precedentes, podemos concluir que la consulta ante la Procuraduría de la Defensa del Contribuyente es una figura jurídica similar al contencioso de interpretación (en la modalidad de recurso directo de interpretación), dado que en ambas figuras lo que pretende el interesado es conocer el alcance, sentido e interpretación de una norma jurídica; en el caso de la consulta ante la referida Procuraduría, de normas fiscales o aduaneras y, tratándose, por ejemplo, del recurso de interpretación venezolano, de textos legales de contenido administrativo y de normas constitucionales.

\section{La consulta ante el Servicio de Administración Tributaria}

Otra figura jurídica prevista en la legislación fiscal mexicana similar al contencioso de interpretación (en la vía de recurso directo de interpretación), es la consulta ante el Servicio de Administración 
Tributaria (también llamada consulta fiscal), la cual se encuentra prevista en el artículo 34 del Código Fiscal de la Federación, mismo que dispone lo siguiente:

Artículo 34. Las autoridades fiscales solo estarán obligadas a contestar las consultas que sobre situaciones reales y concretas les hagan los interesados individualmente.

La autoridad quedará obligada a aplicar los criterios contenidos en la contestación a la consulta de que se trate, siempre que se cumpla con lo siguiente:

I. Que la consulta comprenda los antecedentes y circunstancias necesarias para que la autoridad se pueda pronunciar al respecto.

II. Que los antecedentes y circunstancias que originen la consulta no se hubieren modificado posteriormente a su presentación ante la autoridad.

III. Que la consulta se formule antes de que la autoridad ejerza sus facultades de comprobación respecto de las situaciones reales y concretas a que se refiere la consulta.

La autoridad no quedará vinculada por la respuesta otorgada a las consultas realizadas por los contribuyentes cuando los términos de la consulta no coincidan con la realidad de los hechos o datos consultados o se modifique la legislación aplicable.

Las respuestas recaídas a las consultas a que se refiere este artículo no serán obligatorias para los particulares, por lo cual éstos podrán impugnar, a través de los medios de defensa establecidos en las disposiciones aplicables, las resoluciones definitivas en las cuales la autoridad aplique los criterios contenidos en dichas respuestas.

Las autoridades fiscales deberán contestar las consultas que formulen los particulares en un plazo de tres meses contados a partir de la fecha de presentación de la solicitud respectiva.

El Servicio de Administración Tributaria publicará mensualmente un extracto de las principales resoluciones favorables a los contribuyentes a que se refiere este artículo, debiendo cumplir con lo dispuesto por el artículo 69 de este Código.

Conforme a lo transcrito, podemos afirmar que la consulta es la facultad que tienen los contribuyentes para solicitar a las autoridades fiscales federales, de manera individual, que definan cuál es la interpretación o el tratamiento fiscal que debe dársele a una norma legal (fiscal o aduanera), respecto de una situación real y concreta.

La consulta fiscal tiene como finalidad generar seguridad jurídica en el sujeto pasivo de la relación jurídico tributaria (...) respecto del criterio de la autoridad fiscal, cuando estima dudosa la interpretación y/o aplicación de alguna norma legal a una situación real y concreta, para lo cual, acude ante esta solicitándole que emita su opinión en torno a la situación específica consultada" (Sentencia CXXXIX/2011 Suprema Corte de Justicia de la Nación, 2011, 288).

Debe decirse que la figura jurídica en estudio (la consulta fiscal), constituye una de las modalidades del derecho de petición consagrado en el artículo 8 de la Constitución Política de los Estados Unidos Mexicanos, que establece que los funcionarios y empleados públicos respetarán el ejercicio del derecho 
de petición, siempre que este se formule por escrito, de manera pacífica y respetuosa; pero en materia política solo podrán hacer uso de ese derecho los ciudadanos de la República. A toda petición deberá recaer un acuerdo escrito de la autoridad a quien se haya dirigido, la cual tiene obligación de hacerlo conocer en breve término al peticionario. En razón de lo anterior, es evidente que la autoridad fiscal, al dar respuesta a una consulta formulada en términos del artículo 34 del Código Fiscal de la Federación, debe observar los extremos previstos en la citada norma constitucional.

De manera complementaria a lo establecido en el artículo 34 del Código Fiscal de la Federación, en el numeral 9 de la Ley Federal de los Derechos del Contribuyente, se señala que sin perjuicio de lo establecido en el Código Fiscal de la Federación, los contribuyentes podrán formular a las autoridades fiscales consultas sobre el tratamiento fiscal aplicable a situaciones reales y concretas, y que estas deberán contestarlas por escrito en un plazo máximo de tres meses, además de que dicha contestación tendrá carácter vinculatorio para las autoridades fiscales en la forma y términos previstos en el Código Fiscal de la Federación.

Los requisitos para formular la consulta a que se refiere el artículo 34 del Código Fiscal de la Federación son los siguientes: a) que la consulta verse sobre situaciones reales y concretas; b) que se formule de manera individual; c) que comprenda los antecedentes y circunstancias necesarias para que la autoridad se pueda pronunciar al respecto y que los mismos no se hubieren modificado posteriormente a su presentación y d) que se presente antes de que la autoridad ejerza sus facultades de comprobación respecto de las situaciones reales y concretas a que se refiere la consulta.

Además de lo anterior, en atención a lo establecido en los artículos 18 y 18-A del Código Fiscal de la Federación, la promoción relativa a la consulta deberá contener lo siguiente:

a. El nombre, la denominación o razón social y el domicilio fiscal manifestado al registro federal de contribuyentes, para el efecto de fijar la competencia de la autoridad y la clave que le correspondió en dicho registro.

b. Señalar la autoridad a la que se dirige y el propósito de la promoción.

c. La dirección de correo electrónico para recibir notificaciones.

d. Señalar los números telefónicos, en su caso, del contribuyente y el de los autorizados en los términos del artículo 19 del Código Fiscal de la Federación.

e. Señalar los nombres, direcciones y el registro federal de contribuyentes o número de identificación fiscal tratándose de residentes en el extranjero, de todas las personas involucradas en la solicitud o consulta planteada.

f. Describir las actividades a las que se dedica el interesado.

g. Indicar el monto de la operación u operaciones objeto de la promoción.

h. Señalar todos los hechos y circunstancias relacionados con la promoción, así como acompañar los documentos e información que soporten tales hechos o circunstancias.

i. Describir las razones de negocio que motivan la operación planteada.

j. Indicar si los hechos o circunstancias sobre los que versa la promoción han sido previamente planteados ante la misma autoridad u otra distinta, o han sido materia de medios de defensa ante autoridades administrativas 
o jurisdiccionales y, en su caso, el sentido de la resolución.

k. Indicar si el contribuyente se encuentra sujeto al ejercicio de las facultades de comprobación por parte de la Secretaría de Hacienda y Crédito Público o por las Entidades Federativas coordinadas en ingresos federales, señalando los periodos y las contribuciones objeto de la revisión.

1. Mencionar si se encuentra dentro del plazo para que las autoridades fiscales emitan la resolución a que se refiere el artículo 50 del Código Fiscal de la Federación.

Cuando no se cumplan los requisitos anteriores, las autoridades fiscales requerirán al promovente a fin de que en un plazo de diez días cumpla con el requisito omitido. En caso de no subsanarse la omisión en dicho plazo, la promoción se tendrá por no presentada.

De cumplirse cada uno de los requisitos anteriores, las autoridades fiscales estarán obligadas a dar contestación a la consulta que corresponda, en un plazo de tres meses contados a partir de la fecha de presentación de la solicitud respectiva, en el entendido de que si esa contestación es favorable al contribuyente, dichas autoridades quedarán obligadas a aplicar los criterios contenidos en la contestación a la consulta de que se trate, esto es, la contestación tendrá carácter vinculatorio para las autoridades de mérito. Únicamente cuando los términos de la consulta no coincidan con la realidad de los hechos o datos consultados o se modifique la legislación aplicable, las autoridades fiscales no quedarán vinculadas por la respuesta otorgada a las consultas planteadas por los contribuyentes.

En caso de que la respuesta que recaiga a la consulta sea desfavorable, a) la respuesta adversa al particular no surte efecto legal alguno, por lo que no le vincula a su observancia, es decir, no produce afectación a su esfera jurídica; b) únicamente tiene el carácter de resolución, aquella en la que la autoridad aplique el criterio contenido en la respuesta desfavorable, lo que implica que condiciona su eficacia jurídica a la existencia de un acto concreto de aplicación; c) se establece, a favor del particular, la posibilidad de combatir, a través de los medios de defensa -recurso de revocación o juicio de nulidad-, dichas resoluciones" (Sentencia CXXXIX/2011 Suprema Corte de Justicia de la Nación, 2011, 288).

De lo anterior se observa el inconveniente de que cuando la respuesta dada por la autoridad fiscal a la consulta sea desfavorable al contribuyente, este solo podrá quejarse a través de los medios de defensa establecidos en las disposiciones aplicables, una vez que la autoridad aplique el criterio (desfavorable) contenido en la contestación a la consulta de que se trate en una resolución definitiva y, por tanto, produzca afectación a su esfera jurídica.

No obstante que lo precedente transgrede en perjuicio de los particulares el derecho fundamental de acceso a la justicia contenido en el artículo 17 de la Constitución Política de los Estados Unidos Mexicanos, así como el derecho de la tutela judicial efectiva previsto en los artículos 8 y 25 de la Convención Americana sobre Derechos Humanos, en marzo de 2009 la Primera Sala de la Suprema Corte de Justicia de la Nación estableció la siguiente tesis de jurisprudencia:

\author{
Época: Novena Época \\ Registro: 167750 \\ Instancia: Primera Sala \\ Tipo de Tesis: Jurisprudencia
}


Fuente: Semanario Judicial de la Federación y su Gaceta

Tomo XXIX, Marzo de 2009

Materia(s): Constitucional, Administrativa Tesis: 1a./J. 21/2009

Página: 91

CONSULTAS FISCALES. EL ARTÍCULO 34 DEL CÓDIGO FISCAL DE LA FEDERACIÓN NO VIO-

LA LA GARANTÍA DE ACCESO A LA JUSTICIA (LEGISLACIÓN VIGENTE A PARTIR DEL 10. DE ENERO DE 2007). El citado precepto legal, reformado mediante decreto publicado en el Diario Oficial de la Federación el 27 de diciembre de 2006, al establecer que las respuestas recaídas a las consultas fiscales realizadas a la autoridad no son obligatorias para los particulares y que, por ende, éstos sólo pueden impugnar las resoluciones definitivas en las que aquélla aplique los criterios contenidos en dichas respuestas, no viola la garantía de acceso a la justicia contenida en el artículo 17 de la Constitución Política de los Estados Unidos Mexicanos, pues en términos del propio artículo 34 del Código Fiscal de la Federación, tales consultas no son actos vinculatorios que produzcan efectos en la esfera jurídica de los gobernados. En efecto, ante la falta de afectación en la esfera jurídica del contribuyente, no existen elementos para combatir, pues es necesario que se incida en sus derechos para que un tribunal pueda resolver al respecto. Lo anterior es así, porque conforme a la naturaleza de la consulta, la respuesta que recaiga a ésta constituye un medio de certeza en cuanto al criterio sostenido por la Secretaría de Hacienda y Crédito Público en relación con una situación real y concreta, sin que ello implique una afectación jurídica para los gobernados en tanto que no los vincula; de ahí que cuando las respuestas a las aludidas consultas sean desfavorables a los intereses del contribuyente, sólo podrán impugnarse por los medios de defensa establecidos en las disposiciones aplicables, una vez que las autoridades apliquen dicho criterio en una resolución definitiva y, por tanto, se incida en la esfera jurídica del gobernado.

\section{Conclusiones y propuesta para la implementación en México del contencioso de interpretación en la vía de recurso directo de interpretación}

De todo lo expuesto en la presente investigación, podemos llegar a las siguientes conclusiones:

Primera. El rezago jurisdiccional que afecta al Tribunal Federal de Justicia Fiscal y Administrativa constituye no solo un problema para dicho órgano jurisdiccional, sino también para los derechos fundamentales de los justiciables, en la medida en que el retraso en la atención y resolución de los asuntos vulnera tanto la garantía individual consagrada en el artículo 17 de la Constitución General de la República, como el derecho de la tutela judicial efectiva previsto en los artículos 8 y 25 de la Convención Americana sobre Derechos Humanos.

Segunda. Para hacer frente al rezago jurisdiccional, el Tribunal Federal de Justicia Fiscal y Administrativa y los legisladores federales adoptaron medidas para desarrollar e implementar el ambicioso, novedoso y moderno proyecto de justicia fiscal y administrativa denominado juicio en línea; además de ello y con idéntico fin, se reformó la Ley Federal de Procedimiento Contencioso-Administrativo para crear una nueva modalidad de juicio, el llamado juicio en la vía sumaria, teniendo este como característica la 
simplificación y abreviación en los términos procesales. No obstante ello, en el referido órgano de justicia actualmente se sigue observando rezago jurisdiccional, por lo que es necesario implementar nuevos mecanismos para hacer frente a dicho rezago y así poder cumplir con el derecho fundamental previsto en el artículo 17 de la Constitución General de la República, así como con el derecho de la tutela judicial efectiva establecido en los artículos 8 y 25 de la Convención Americana sobre Derechos Humanos.

Tercera. Tradicionalmente, en el sistema contencioso-administrativo francés, se distinguen cuatro tipos de contencioso: el de interpretación, el de represión, el de anulación y el de plena jurisdicción. En el caso mexicano solo se volteó a ver a los dos últimos, dejando de lado al denominado contencioso de interpretación. El contencioso de interpretación -también conocido en otras latitudes como recurso contencioso-administrativo de interpretación, recurso de interpretación o simplemente acción de interpretación-, es aquel que puede promoverse con motivo del surgimiento de una cuestión prejudicial de índole administrativa en una jurisdicción distinta de la contencioso-administrativa (prejudicialidad administrativa en un proceso ordinario), o también en forma autónoma, como un recurso directo de interpretación de actos, contratos administrativos y leyes, según sea el caso. El recurso directo de interpretación tiene por objeto solicitar a un juez una declaración sobre la interpretación que debe dársele a un acto, a un contrato administrativo o a una ley cuyo sentido y alcance sean oscuros, ambiguos o confusos, a efecto de que determine la correcta interpretación de los mismos.

Cuarta. La legislación venezolana permite que en la jurisdicción contencioso-administrativa se pueda interponer el recurso de interpretación legal, pero, a diferencia de otros países, como Panamá, esta no recae sobre actos o contratos administrativos, sino sobre el contenido y alcance de textos legales, específicamente leyes de contenido administrativo y de normas constitucionales.

Quinta. En la jurisdicción contenciosoadministrativa federal mexicana, la única aproximación al contencioso de interpretación (en la vía de recurso de interpretación directo), la encontramos en la Ley Orgánica del Tribunal Federal de Justicia Fiscal y Administrativa, específicamente en la fracción VII del artículo 14, que dispone: El Tribunal Federal de Justicia Fiscal y Administrativa conocerá de los juicios que se promuevan contra las resoluciones definitivas, actos administrativos y procedimientos que se indican a continuación: VII. Las que se dicten en materia administrativa sobre interpretación y cumplimiento de contratos de obras públicas, adquisiciones, arrendamientos y servicios celebrados por las dependencias y entidades de la Administración Pública Federal.

Sexta. En México, si bien existen figuras jurídicas (no jurisdiccionales) similares al contencioso de interpretación en la vía de recurso directo de interpretación, como son la consulta que se tramita ante la Procuraduría de la Defensa del Contribuyente y la también denominada consulta cuyo trámite se realiza ante el Servicio de Administración Tributaria; debe decirse que ambas consultas presentan inconveniencias, toda vez que lo resuelto en la primera solo refleja las opiniones de la citada Procuraduría en su carácter de órgano técnico especializado en materia tributaria, por lo que el dictamen que se emite en una consulta de esa naturaleza constituye una mera opinión técnica en materia fiscal, no vinculatoria para las autoridades 
fiscales, en tanto que la segunda tiene como inconveniente que, cuando la respuesta dada por la autoridad fiscal a la consulta es desfavorable al contribuyente, este solo puede inconformarse a través de los medios de defensa establecidos en las disposiciones aplicables una vez que la autoridad le aplica el criterio (desfavorable) en una resolución definitiva y, por tanto, produzca afectación a su esfera jurídica.

Séptima. Por las razones anteriores, estimamos que la implementación en México del contencioso de interpretación en la vía de recurso directo de interpretación, en términos similares al contemplado en la legislación venezolana, constituiría un gran avance y mejoría para la justicia administrativa mexicana, puesto que, al ser un procedimiento sencillo, ágil y eficaz (como se verá en la propuesta que más adelante se plantea), serviría para hacer frente al rezago jurisdiccional que agobia al Tribunal Federal de Justicia Fiscal y Administrativa, y con ello se respetaría -en beneficio de los justiciables- el derecho fundamental previsto en el artículo 17 de la Constitución General de la República, así como el derecho de la tutela judicial efectiva establecido en los artículos 8 y 25 de la Convención Americana sobre Derechos Humanos. Adicionalmente a ello, con la decisión que adopte el órgano jurisdiccional que conozca del recurso directo de interpretación, se otorgaría certeza jurídica al particular en su relación con las autoridades fiscales y administrativas federales, al quedar definido el sentido, alcance o la inteligencia que debe dárseles a textos legales de índole fiscal y administrativa cuando estos resultaren oscuros, ambiguos o confusos. Asimismo, la adopción en el sistema jurídico mexicano de un procedimiento como el que nos ocupa permitiría la unifi- cación de criterios sobre la interpretación de leyes fiscales y administrativas, con lo que se preserva la uniformidad de la interpretación legal y se garantiza la seguridad jurídica del particular.

En virtud de las conclusiones precedentes, a continuación presentamos la propuesta de procedimiento contencioso de interpretación en la vía de recurso directo de interpretación, la cual, desde nuestra óptica, de ser incluida (previa reforma constitucional) en la Ley Federal de Procedimiento Contencioso-Administrativo. Como ya se ha dicho, constituiría un gran avance y mejoría para la justicia administrativa en México.

\section{LEY FEDERAL DE PROCEDIMIENTO CON- \\ TENCIOSO-ADMINISTRATIVO \\ CAPÍTULO XII \\ DEL PROCEDIMIENTO CONTENCIOSO DE INTERPRETACIÓN}

- El procedimiento contencioso de interpretación se tramitará y resolverá de conformidad con las disposiciones específicas que se establecen en este Capítulo y, en lo no previsto, se aplicarán las demás disposiciones de esta ley. De dicho procedimiento sólo podrán conocer las Secciones de la Sala Superior del Tribunal Federal de Justicia Fiscal y Administrativa.

- Cualquier persona podrá promover procedimiento contencioso de interpretación respecto de situaciones reales y concretas, en aquellos casos en que estime que una normal fiscal o administrativa resulte ambigua, imprecisa o confusa, para el único efecto de que el Tribunal decida el sentido, alcance e inteligencia que debe dársele al texto legal cuya interpretación se solicita. La solicitud de mérito podrá presentarse en cualquier tiempo. 
- La decisión interpretativa que adopten las Secciones no tendrá efectos generales, y deberá limitarse a determinar el sentido, alcance e inteligencia de una norma fiscal o administrativa respecto de los solicitantes.

- La solicitud de interpretación deberá indicar:

I. El nombre del solicitante, domicilio fiscal y su domicilio para oír y recibir notificaciones en cualquier parte del territorio nacional.

II. Las normas fiscales o administrativas cuya interpretación se solicita, explicando la ambigüedad, imprecisión o confusión de las mismas.

III. Los antecedentes y circunstancias necesarias para que el Tribunal se pueda pronunciar al respecto.

IV. Las pruebas que ofrezca.

V. El nombre y domicilio del tercero interesado, cuando lo haya.

- Cuando se omitan los datos precisados en las fracciones I, II, III y IV, el Magistrado Instructor requerirá al promovente para que los señale dentro del término de cinco días, apercibiéndolo que de no hacerlo en tiempo se tendrá por no presentada la solicitud de interpretación o por no ofrecidas las pruebas, según corresponda.

- El promovente deberá adjuntar a su solicitud de interpretación:

I. Una copia de la misma y de los documentos anexos para cada una de las au- toridades involucradas en las situaciones reales y concretas atinentes a la solicitud de interpretación, así como para el Poder Legislativo.

II. El documento que acredite su personalidad o en el que conste que le fue reconocida por la autoridad fiscal o administrativa, o bien señalar los datos de registro del documento con la que esté acreditada ante el Tribunal, cuando no gestione en nombre propio.

III. Las pruebas documentales que ofrezca.

- Si no se adjuntan los documentos anteriores, el Magistrado Instructor requerirá al promovente para que los presente dentro del plazo de cinco días. Cuando el promovente no los presente dentro de dicho plazo y se trate de los documentos a que se refieren las fracciones I y II, se tendrá por no presentada petición de interpretación. Si se trata de las pruebas a que se refiere la fracción III, las mismas se tendrán por no ofrecidas.

- En contra del acuerdo que tenga por no presentada la solicitud de interpretación o por no ofrecidas las pruebas, procederá el recurso de reclamación previsto en esta ley, el cual deberá interponerse ante la Sección que corresponda dentro del plazo de cinco días siguientes a aquél en que surta efectos su notificación.

- Cuando el promovente tenga su domicilio fuera de la población donde esté la sede de la Sección, la solicitud de interpretación y cualquier promoción podrán enviarse a través de Correos de México, correo certificado con acuse de recibo. 
- En el acuerdo que admita a trámite la solicitud de interpretación, el Magistrado Instructor ordenará correr traslado a las autoridades fiscales o administrativas involucradas en las situaciones reales y concretas atinentes a dicha solicitud, así como al Poder Legislativo, a efecto de que dentro del plazo de cinco días manifiesten la interpretación que a su juicio debe darse a las normas materia de la solicitud de referencia.

- En dicho acuerdo y siempre que el solicitante lo pida expresamente, la Procuraduría de la Defensa del Contribuyente podrá intervenir en el procedimiento contencioso de interpretación, únicamente como coadyuvante en la solución del caso. Una vez notificada dicha Procuraduría tendrá cinco días para presentar al Tribunal una propuesta sobre el sentido, alcance e inteligencia que debe darse a la ley fiscal o administrativa cuya interpretación se solicita.

- Vencido el plazo señalado, con propuesta o sin ella, y una vez transcurrido el término concedido a la Procuraduría de la Defensa del Contribuyente, la Sección a quien corresponda el conocimiento del asunto emitirá su decisión dentro de los treinta días siguientes.

- La decisión que adopte el Tribunal sobre el sentido, alcance e inteligencia que debe darse a la ley fiscal o administrativa cuya interpretación se solicita, será obligatoria para las partes y no podrá ser impugnada a través de ningún medio de defensa, salvo que se trate del solicitante, quien podrá interponer juicio de amparo.

- La solicitud de interpretación será improcedente: a) Cuando exista jurisprudencia de la Suprema Corte de Justicia de la Nación o del Pleno de la Sala Superior del Tribunal Federal de Justicia Fiscal y Administrativa, respecto de la norma sobre la que verse la solicitud de interpretación.

b) Cuando la solicitud interpretación verse sobre la inconstitucionalidad o inconvencionalidad de una norma fiscal o administrativa.

Con independencia de lo anterior, si alguna de las Secciones advierte que una norma fiscal o administrativa contraviene la Constitución o algún tratado internacional en materia de derechos humanos podrá, de oficio, resolver que se inaplique dicha norma en beneficio del solicitante.

c) Cuando los antecedentes y circunstancias materia de la solicitud estén sometidos a discusión en un recurso administrativo o en un juicio ante los tribunales federales.

d) Cuando la solicitud no verse sobre situaciones reales y concretas.

e) Cuando se pretenda la interpretación de normas diversas a las fiscales y administrativas.

- En todos los casos en que la normal fiscal o administrativa respecto de la cual se solicita la interpretación involucre derechos humanos previstos en la Constitución Política de los Estados Unidos Mexicanos y en los tratados internacionales de los que el Estado Mexicano sea parte, de conformidad con lo dispuesto en el artículo $1^{\circ}$ constitucional, el Tribunal deberá de aplicar el principio pro persona. 


\section{Referencias}

\section{Bibliográficas}

Arcaya, P. M. (1957). "Cualidad e Interés en las Acciones Meramente Declarativas y Constitutivas”, en Revista de la Facultad de Derecho de la Universidad Central de Venezuela, Caracas, núm. 11,

Arreola Talavera, R. (2015). "El Contencioso de Interpretación en México", en Revista Digital Praxis de la Justicia Fiscal y Administrativa, marzo de 2013, México, Año V, núm. 12, p.13. Disponible en http://www.tfjfa. gob.mx/investigaciones/pdf/elcontenciosodeinterpretacionenmexico.pdf. Consultado el 9 de febrero de 2015 .

Batista Domínguez, A. (2007). "El contencioso de interpretación prejudicial como mecanismo de control de la administración pública panameña”, en Cisneros Farías, G. et al. (coords.), El Control de la Administración Pública, Segundo Congreso Iberoamericano de Derecho Administrativo. México: Universidad Nacional Autónoma de México.

Briseño Sierra,H.(1968). El Proceso Administrativo en Iberoamérica. México: Universidad Nacional Autónoma de México.

Brewer-Carias, A.R. y Pérez Olivares, E. (1965). "El Recurso Contencioso-Administrativo de Interpretación en el Sistema Jurídico Venezolano", en Revista de la Facultad de Derecho. Caracas, núm. 32.

Escudero León, Margarita (2005). El Control Judicial de Constitucionalidad sobre las Ramas Legislativa y Ejecutiva del Poder Público. Venezuela: Ediciones de la Facultad de Ciencias Jurídicas y Políticas de la U.C.V.

Fernández Ruiz, J. (2006). "Apuntes históricos sobre la ciencia del derecho administrativo en México", en González Martín, Nuria (coord.), Estudios jurídicos en homenaje a Martha Morineau. México: Universidad Nacional Autónoma de México.

Márquez Gómez, D. (2002). Los procedimientos administrativos materialmente jurisdiccionales como medios de control en la administración pública. México: Universidad Nacional Autónoma de México.

Pérez Olivares, E. (1979). El recurso de interpretación. Venezuela: Instituto de Derecho Público de la Facultad de Ciencias Jurídicas y Políticas de la Universidad Central de Venezuela.

Pérez Salazar, G. (2001). "El recurso de interpretación en Venezuela", en Revista de la Facultad de Ciencias Jurídicas y Políticas de la Universidad Central de Venezuela/Universidad Central de Venezuela, Facultad de Ciencias Jurídicas y Políticas. Caracas, núm. 120.

Sanjur, O. (1990). "Los contenciosos de interpretación y apreciación de validez y su relación con el proceso civil”, en Fábrega, J. (comp.), Estudios procesales. Panamá: Editora Jurídica Panameña.

Vásquez Alfaro, J.L. (1991). Evolución y Perspectiva de los Órganos de Jurisdicción Administrativa en el Ordenamiento Mexicano. México: Instituto de Investigaciones Jurídicas.

\section{Normatividad}

Código Fiscal de la Federación, 2015, México.

Constitución de la República Bolivariana de Venezuela, 2015, Venezuela.

Constitución Política de los Estados Unidos Mexicanos, 2015, México.

Ley Orgánica de la Jurisdicción Contencioso Administrativa, 2015, Venezuela.

Ley Orgánica del Tribunal Federal de Justicia Fiscal y Administrativa, 2015, México.

Ley Orgánica de la Procuraduría de la Defensa del Contribuyente, 2015, México.

Ley Orgánica del Tribunal Supremo de Justicia de Venezuela, 2015, Venezuela. 
Ley del Servicio de Administración Tributaria, 2015, México.

Lineamientos que regulan el ejercicio de las atribuciones sustantivas de la Procuraduría de la Defensa del Contribuyente, 2015, México.

\section{Enlaces electrónicos}

http://www.prodecon.gob.mx/Mision.html

http://www.scjn.gob.mx/

http://www.tfjfa.gb.mx

http://www.tsj.gov.ve/

http://es.wikipedia.org/wiki/Unidad_Tributaria

http://www.vie-publique.fr/decouverte-institutions/institutions/approfondissements/quatre-typescontentieuxadministratif.html. Consultado el 4 de febrero de 2015. 